\title{
Novel Organotin(IV) Schiff Base Complexes with Histidine Derivatives: Synthesis, Characterization, and Biological Activity
}

\author{
Ariadna Garza-Ortiz, ${ }^{1}$ Carlos Camacho-Camacho, ${ }^{1}$ Teresita Sainz-Espuñes, ${ }^{1}$ \\ Irma Rojas-Oviedo, ${ }^{1}$ Luis Raúl Gutiérrez-Lucas, ${ }^{1}$ \\ Atilano Gutierrez Carrillo, ${ }^{2}$ and Marco A. Vera Ramirez ${ }^{2}$ \\ ${ }^{1}$ Departamento de Sistemas Biológicos, Universidad Autónoma Metropolitana-Unidad Xochimilco, Calzada de Hueso 1100, \\ Colonia Villa Quietud, 04960 Coyoacán, D.F., Mexico \\ ${ }^{2}$ Departamento de Resonancia Magnética Nuclear, Universidad Autónoma Metropolitana, Unidad Iztapalapa, San Rafael Atlixco, \\ No. 186, Col. Vicentina, 09340 Iztapalapa, D.F., Mexico
}

Correspondence should be addressed to Carlos Camacho-Camacho; ccamacho@correo.xoc.uam.mx

Received 18 March 2013; Accepted 2 June 2013

Academic Editor: Claudio Pettinari

Copyright (C) 2013 Ariadna Garza-Ortiz et al. This is an open access article distributed under the Creative Commons Attribution License, which permits unrestricted use, distribution, and reproduction in any medium, provided the original work is properly cited.

Five novel tin Schiff base complexes with histidine analogues (derived from the condensation reaction between L-histidine and 3,5-di-tert-butyl-2-hydroxybenzaldehyde) have been synthesized and characterized. Characterization has been completed by IR and high-resolution mass spectroscopy, $1 \mathrm{D}$ and $2 \mathrm{D}$ solution NMR $\left({ }^{1} \mathrm{H},{ }^{13} \mathrm{C}\right.$ and $\left.{ }^{119} \mathrm{Sn}\right)$, as well as solid state ${ }^{119} \mathrm{Sn} \mathrm{NMR}$. The spectroscopic evidence shows two types of structures: a trigonal bipyramidal stereochemistry with the tin atom coordinated to five donating atoms (two oxygen atoms, one nitrogen atom, and two carbon atoms belonging to the alkyl moieties), where one molecule of ligand is coordinated in a three dentate fashion. The second structure is spectroscopically described as a tetrahedral tin complex with four donating atoms (one oxygen atom coordinated to the metal and three carbon atoms belonging to the alkyl or aryl substituents), with one molecule of ligand attached. The antimicrobial activity of the tin compounds has been tested against the growth of bacteria in vitro to assess their bactericidal properties. While pentacoordinated compounds 1, 2, and $\mathbf{3}$ are described as moderate effective to noneffective drugs against both Gram-positive and Gram-negative bacteria, tetracoordinated tin(IV) compounds $\mathbf{4}$ and $\mathbf{5}$ are considered as moderate effective and most effective compounds, respectively, against the methicillinresistant Staphylococcus aureus strains (Gram-positive).

\section{Introduction}

The use of metal complexes as chemotherapeutic agents in the treatment of illness, which are a major public health concern, appears as a very attractive alternative. The success of cisplatin for the treatment of testicular and ovarian cancer attracted research attention to other metal-based antineoplastic agents. Metal-based compounds are of particular interest due to their physical and chemical properties. Properties such as ligand exchange rates, redox properties, oxidation states, coordination affinities, solubility, biodisponibility, and biodistribution could be modified in order to increase the therapeutic effect while reducing the side effects.
Although the design of a metal-based compound with good therapeutic index is still rather empirical, a number of potential metal-based bactericide compounds have been fully described in the literature. The evidence about specific or selective bonding of metals and organometallic species to donor sites in biological structures is very limited, so trustable mechanisms of biological activity and valid structure-activity relationships are limited as well.

One approach that could produce successful results involves the metal coordination of ligands with well-known biological activity. In this way, the designed metal-based compound combines ligands with an important biological activity and pharmacologically active metals in a single 
chemical moiety. This strategy could produce enhanced efficacy and reduced toxic or side effects while lowering the therapeutic doses and/or overcoming drug resistance mechanisms. Additionally the metal could act as a carrier and/or stabilizer of the drug until it is able to reach the target. At the same time, the organic ligand with well-known biological activity could transport and protect the metal, then avoiding side reactions on its route to the potential targets. The metal-ligand combined effects may result in an important improvement in the activity of the resulting coordination compounds $[1,2]$.

Amino acids and their derivatives are excellent ligand candidates due to their coordination properties and biological importance. In addition, their solubility properties and specific mechanisms of transport could facilitate their biological uptake. In particular histidine is a very important bioactive amino acid with multiple physiological functions.

The histidine binding to transition metal ions in biological systems has a major physicochemical role in several proteins, as the X-ray structural determination studies of metalloproteins like carbonic anhydrase, carboxypeptidase, plastocyanin, or azurin among others have demonstrated [3]. Additionally, histidine plays a major role in the zinc metabolism acting as the major zinc binding moiety in serum [4].

Schiff bases represent an important group of compounds in organic chemistry because they are starting materials in the synthesis of industrial products where carbon-nitrogen bonds are present [5]. In particular, this $\mathrm{N}-\mathrm{C}$ bond is involved in several biological functions allowing the Schiff bases to behave, for instance, as antimicrobial, anti-inflamatory, antitumour, or antiviral drugs [6].

The design of organotin derivatives with biologically important ligands, like antibiotics $[7,8]$, anticancer drugs, [9] and some other biologically relevant substrates [10], has been explored in the past years [11]. Organotin derivatives of amino acids have been of interest as possible biocides [12]; for example, tricyclohexyltin alaninate is a powerful fungicide and bactericide [13]. This compound has been described as a substrate of peptide syntheses as well [14]. Amino acids and dipeptides which are considered potentially polydentate ligands could afford interesting structural possibilities when coordinated to organotin(IV) groups, since organotin(IV) compounds adopt higher coordination numbers whenever favorable conditions exist [15].

One of our research goals is the study of organotin(IV) compounds with important biological activity. In this order of ideas we designed, prepared, and characterized diorganotin and triorganotin derivatives of an L-histidine Schiff base analogue, with biological application as antibacterial compounds. The L-histidine derivative was obtained by condensation reaction of L-histidine and 3,5-di-tert-butyl2-hydroxybenzaldehyde. Posterior complexation of the Lhistidine analogue was achieved with tin(IV) organometallic reagents.

To the best of our knowledge there are no reports on organotin(IV) compounds of L-histidine Schiff base derivatives. We have characterized these compounds not only spectroscopically but also with regard to their antibacterial activity against Escherichia coli, Staphylococcus aureus, Pseudomona aeruginosa, Shigella dysenteriae, Salmonella typhimurium, Salmonella typhi, Proteus mirabilis, Klebsiella pneumonia, and Serratia marcescens. The compounds described in this work are all new and some of them showing promising antibacterial activity for methicillin-resistant Staphylococcus aureus strains (Gram-positive).

\section{Experimental}

2.1. Materials and Methodology. Di-n-methyltin oxide, Di- $n$-butyltin oxide, di- $n$-phenyl oxide, bis- $n$-tributyltin oxide, triphenyltin hydroxide, L-histidine 99\%, and 3,5-ditert.butyl-2-hydroxybenzaldehyde $99 \%$ were purchased from Aldrich and were used without further purification. Solvents were freshly distilled before use following the standard procedures. Elemental analyses were performed in an Eager 300 analyzer. IR spectra were obtained on a Nicolet FT-55X apparatus as $\mathrm{KBr}$ discs of each compound. Melting points were measured on a Fisher-Johns melting point apparatus and are uncorrected. ${ }^{1} \mathrm{H},{ }^{13} \mathrm{C}$ and ${ }^{119} \mathrm{Sn}$ NMR spectra were recorded with a Varian spectrometer operating at $300 \mathrm{MHz}$ using $\mathrm{CDCl}_{3}$ or $\mathrm{CD}_{3} \mathrm{OD}$ as solvent and TMS as a reference. Solid state ${ }^{119}$ Sn NMR spectra were recorded with a Bruker AVANCE-II, $300 \mathrm{MHz}$ NMR spectrometer, using a $4 \mathrm{~mm}$ CP-MAS probe. ${ }^{119} \mathrm{Sn}$ chemical shift referencing is toward tetramethyltin. High-resolution mass spectra were obtained by LC/MSD TOF on an Agilent Technologies instrument with APCI as ionization source.

\subsubsection{Synthesis of Tin Derivatives}

Compounds 1-5. To a solution of 3,5-di-tert-butyl-2hydroxybenzaldehyde ( $2 \mathrm{mmol}, 468 \mathrm{mg}$ ) in $16 \mathrm{~mL}$ of toluene at RT, L-histidine ( $2 \mathrm{mmol}, 310.32 \mathrm{mg}), 6 \mathrm{~mL}$ of ethanol, and the corresponding tin derivative $(2 \mathrm{mmol})$ were successively added to a flask equipped with a Dean-Stark moisture trap (filled with dry toluene). After $24 \mathrm{~h}$ under gentle reflux, the solvents were evaporated giving yellow solids in all cases. Purification was achieved by recrystallization from dichloromethane-hexane $(3: 1)$ mixtures.

$\left[\left(\mathrm{C}_{21} \mathrm{H}_{27} \mathrm{~N}_{3} \mathrm{O}_{3}\right) \mathrm{Sn}\left(\mathrm{CH}_{3}\right)_{2}\right]\left(0.4 \mathrm{CH}_{2} \mathrm{Cl}_{2}\right)$ (1). A yellow crystalline solid 1 was obtained in moderate yield $(350 \mathrm{mg}$, $33.76 \%)$. Elemental analysis for $\mathrm{C}_{23,4} \mathrm{H}_{33,8} \mathrm{Cl}_{0,8} \mathrm{~N}_{3} \mathrm{O}_{3} \mathrm{Sn}$ : Calcd (\%): C, 50.90; N, 7.61; H, 6.17. Found (\%): C, 50.96; N, 7.27; H, 5.75. IR (KBr disk) $\mathrm{cm}^{-1}: 3445 \mathrm{~s}, 2958-2869 \mathrm{~s}, 1659 \mathrm{~s}$, $1613 \mathrm{~s}, 1539 \mathrm{~m}, 1461 \mathrm{w}, 1429 \mathrm{~m}, 1362 \mathrm{~m}, 1172 \mathrm{~m}, 784 \mathrm{w}, 746 \mathrm{w}$, $655 \mathrm{w}, 623 \mathrm{w}, 530 \mathrm{w}, 470 \mathrm{w} . \mathrm{mp}=171-174^{\circ} \mathrm{C}$. Electrospray mass (masses given based on ${ }^{1} \mathrm{H},{ }^{12} \mathrm{C},{ }^{16} \mathrm{O},{ }^{14} \mathrm{~N}$, and

${ }^{120} \mathrm{Sn}$ ): the isotopic distributions were compared with the calculated. Only tin-containing fragments are given, $m / z$ : $\left[\mathrm{M}^{+}\right]\left(\left[\left(\mathrm{C}_{21} \mathrm{H}_{28} \mathrm{~N}_{3} \mathrm{O}_{3}\right) \mathrm{Sn}\left(\mathrm{CH}_{3}\right)_{2}\right]^{+}\right), 520$ (100\%); $\left(3\left[\mathrm{M}^{+}\right]+\right.$ $\left.\mathrm{CH}_{2} \mathrm{Cl}_{2}\right), 542(16 \%) ;\left(\left[\mathrm{M}^{+}\right]+\mathrm{M}\right), 1037$ (7\%).

$\left[\left(\mathrm{C}_{21} \mathrm{H}_{27} \mathrm{~N}_{3} \mathrm{O}_{3}\right) \mathrm{Sn}\left(\mathrm{CH}_{2} \mathrm{CH}_{2} \mathrm{CH}_{2} \mathrm{CH}_{3}\right)_{2}\right]\left(0.5 \mathrm{CH}_{2} \mathrm{Cl}_{2}\right)$ (2). A yellow crystalline solid 2 was obtained in moderate yield (520 mg, 43.16\%). Elemental analysis for $\mathrm{C}_{29,5} \mathrm{H}_{46} \mathrm{ClN}_{3} \mathrm{O}_{3} \mathrm{Sn}$ : 
Calcd(\%): C, 54.94; N, 6.52; H, 7.19. Found (\%): C, 54.70; $\mathrm{N}, 6.08$; H, 7.32. IR (KBr disk) $\mathrm{cm}^{-1}: 3447 \mathrm{~m}, 3276 \mathrm{~m}, 2958-$ $2869 \mathrm{~s}, 1668 \mathrm{~s}, 1611 \mathrm{~s}, 1539 \mathrm{~m}, 1460-1426 \mathrm{~m}, 1363 \mathrm{~m}, 1172 \mathrm{~m}$, $840 \mathrm{w}, 746 \mathrm{w}, 655 \mathrm{w}, 622 \mathrm{w}, 532 \mathrm{w}, 480 \mathrm{w} . \mathrm{mp}=110-116^{\circ} \mathrm{C}$. Electrospray mass (masses given based on ${ }^{1} \mathrm{H},{ }^{12} \mathrm{C},{ }^{16} \mathrm{O}$, ${ }^{14} \mathrm{~N}$, and ${ }^{120} \mathrm{Sn}$ ): the isotopic distributions were compared with the calculated. Only tin-containing fragments are given, $m / z:\left[\mathrm{M}^{+}\right]\left(\left[\left(\mathrm{C}_{21} \mathrm{H}_{28} \mathrm{~N}_{3} \mathrm{O}_{3}\right) \mathrm{Sn}\left(\mathrm{CH}_{2} \mathrm{CH}_{2} \mathrm{CH}_{2} \mathrm{CH}_{3}\right)_{2}\right]^{+}\right), 604$ $(100 \%) ;\left(4\left[\mathrm{M}^{+}\right]+\mathrm{CH}_{2} \mathrm{Cl}_{2}\right), 625(11 \%) ;\left(\left[\mathrm{M}^{+}\right]+\mathrm{M}\right), 1205(3 \%)$.

[( $\left.\left.\mathrm{C}_{21} \mathrm{H}_{27} \mathrm{~N}_{3} \mathrm{O}_{3}\right) \mathrm{Sn}\left(\mathrm{C}_{6} \mathrm{H}_{5}\right)_{2}\right]$ (3). A yellow solid 3 was obtained in moderate yield (660 mg, 47.66\%). Elemental analysis for $\mathrm{C}_{33} \mathrm{H}_{37} \mathrm{~N}_{3} \mathrm{O}_{3} \mathrm{Sn}$ : Calcd(\%): C, 61.70; N, 6.54; $\mathrm{H}$, 5.81. Found(\%): C, 61.59; N, 6.39; H, 5.21. IR $(\mathrm{KBr}$ disk) $\mathrm{cm}^{-1}: 3448 \mathrm{~m}, 3306 \mathrm{~m}, 2957-2870 \mathrm{~s}, 1668 \mathrm{w}, 1618 \mathrm{~s}$, $1538 \mathrm{~m}, 1461 \mathrm{~m}, 1431 \mathrm{~m}, 1361 \mathrm{~m}, 1253 \mathrm{~m}, 1171 \mathrm{~m}, 837 \mathrm{w}, 731 \mathrm{~m}$, $654 \mathrm{w}, 620 \mathrm{w}, 536 \mathrm{w}, 450 \mathrm{w} . \mathrm{mp}=181-185^{\circ} \mathrm{C}$. Electrospray mass (masses given based on ${ }^{1} \mathrm{H},{ }^{12} \mathrm{C},{ }^{16} \mathrm{O},{ }^{14} \mathrm{~N}$, and ${ }^{120} \mathrm{Sn}$ ): the isotopic distributions were compared with the calculated. Only tin-containing fragments are given, $m / z$ : $\left[\mathrm{M}^{+}\right]\left(\left[\left(\mathrm{C}_{21} \mathrm{H}_{28} \mathrm{~N}_{3} \mathrm{O}_{3}\right) \mathrm{Sn}\left(\mathrm{C}_{5} \mathrm{H}_{5}\right)_{2}\right]^{+}\right), 643$ (100\%); $\left(4\left[\mathrm{M}^{+}\right]+\right.$ $\left.\mathrm{CH}_{2} \mathrm{Cl}_{2}\right), 666(12 \%) ;\left(\left[\mathrm{M}^{+}\right]+\mathrm{M}\right), 1285(6 \%)$.

[ $\left.\left(\mathrm{C}_{21} \mathrm{H}_{28} \mathrm{~N}_{3} \mathrm{O}_{3}\right) \mathrm{Sn}\left(\mathrm{CH}_{2} \mathrm{CH}_{2} \mathrm{CH}_{2} \mathrm{CH}_{3}\right)_{3}\right]$ (4). A yellow crystalline solid 4 was obtained in moderate yield (410 mg, $31.03 \%)$. Elemental analysis for $\mathrm{C}_{33} \mathrm{H}_{55} \mathrm{~N}_{3} \mathrm{O}_{3} \mathrm{Sn}$ : Calcd(\%): C, 60.01; N, 6.36; H, 8.39. Found(\%): C, 60.29; N, 6.46; $\mathrm{H}, 7.99$. IR ( $\mathrm{KBr}$ disk) $\mathrm{cm}^{-1}$ : $3091 \mathrm{w}$ br, 2955-2866 s, $1611 \mathrm{~s}$, 1460-1439 m, 1366 s, 1269-1239 m, 1174 w, 818 s, 655 m, 450 w. $\mathrm{mp}=200-203^{\circ} \mathrm{C}$. Electrospray mass (masses given based on ${ }^{1} \mathrm{H},{ }^{12} \mathrm{C},{ }^{16} \mathrm{O},{ }^{14} \mathrm{~N}$, and ${ }^{120} \mathrm{Sn}$ ): the isotopic distributions were compared with the calculated. Only tin-containing fragments are given, $m / z$ : $\left[\mathrm{HSn}\left(\mathrm{CH}_{2} \mathrm{CH}_{2} \mathrm{CH}_{2} \mathrm{CH}_{3}\right)_{3}{ }^{+}\right.$], 291 (87\%); $\left[\mathrm{M}^{+}\right]\left(\left[\left(\mathrm{C}_{21} \mathrm{H}_{29} \mathrm{~N}_{3} \mathrm{O}_{3}\right) \mathrm{Sn}\left(\mathrm{CH}_{2} \mathrm{CH}_{2} \mathrm{CH}_{2} \mathrm{CH}_{3}\right)_{3}\right]^{+}\right), 662$ (100\%); $\left(\left[\mathrm{M}^{+}\right]+\mathrm{Bu}_{3} \mathrm{Sn}\right), 951(41 \%)$.

$\left[\left(\mathrm{C}_{21} \mathrm{H}_{28} \mathrm{~N}_{3} \mathrm{O}_{3}\right) \mathrm{Sn}\left(\mathrm{C}_{6} \mathrm{H}_{5}\right)_{3}\right]\left(2.2 \mathrm{CH}_{2} \mathrm{Cl}_{2}\right)\left(3.6 \mathrm{C}_{6} \mathrm{H}_{5} \mathrm{CH}_{3}\right)$ A yellow solid 5 was obtained in moderate yield $(380 \mathrm{mg}$, 15.52\%). Elemental analysis for $\mathrm{C}_{66.4} \mathrm{H}_{76.2} \mathrm{~N}_{3} \mathrm{O}_{3} \mathrm{SnCl}_{4.4}$ Calcd(\%): C, 64.37; N, 3.39; H, 6.20. Found(\%): C, 64.27; $\mathrm{N}, 3.35$; H, 5.56. IR (KBr disk) $\mathrm{cm}^{-1}$ : 3266-3060 m, 2958$2864 \mathrm{~s}, 1962-1716 \mathrm{w}, 1631-1595 \mathrm{~s}, 1479 \mathrm{~m}, 1427 \mathrm{~s}, 1361 \mathrm{~m}$, $1260 \mathrm{w}, 1180 \mathrm{w}, 1073 \mathrm{~s}, 729\left(\mathrm{CH}_{2} \mathrm{Cl}_{2}\right) \mathrm{s}, 697\left(\mathrm{CH}_{2} \mathrm{Cl}_{2}\right) \mathrm{s}$, $657 \mathrm{~m}, 455 \mathrm{~m}, 443 \mathrm{~m} . \mathrm{mp}=203-205^{\circ} \mathrm{C}$. Electrospray mass (masses given based on ${ }^{1} \mathrm{H},{ }^{12} \mathrm{C},{ }^{16} \mathrm{O},{ }^{14} \mathrm{~N}$, and ${ }^{120} \mathrm{Sn}$ ): the isotopic distributions were compared with the calculated. Only tin-containing fragments are given, $m / z$ : $\left[\mathrm{M}^{+}\right]$ $\left(\left[\left(\mathrm{C}_{21} \mathrm{H}_{29} \mathrm{~N}_{3} \mathrm{O}_{3}\right) \mathrm{Sn}\left(\mathrm{C}_{6} \mathrm{H}_{5}\right)_{3}\right]^{+}\right), 722$ (23\%); $\left[\mathrm{C}_{21} \mathrm{H}_{29} \mathrm{~N}_{3} \mathrm{O}_{3}\right]^{+}$, $371(22 \%) ;\left[\mathrm{C}_{6} \mathrm{H}_{5}\right]^{+}, 77(100 \%)$.

\subsubsection{Biological Activity: Antibacterial Screening}

Bacterial Strains. Bacterial reference cultures and selfcollection strains were used to test a broad spectrum of bacteria. The strains used in this study were Enterohemorrhagic Escherichia coli EDL933, Staphylococcus aureus MRSA, Pseudomona aeruginosa ATCC27853, Shigella dysenteriae FMUNAM98863, Salmonella typhimurium ATCC14028, Salmonella typhi FMUNAM95073, Proteus mirabilis RTX339, Klebsiella pneumoniae ATCC8045, and Serratia marcescens TSUAM1.

Isolates of methicillin-resistant $S$. aureus (MRSA) were obtained from our collection [16]. Identification of $S$. aureus was performed by the coagulase test with human plasma. MRSA strains were confirmed to be methicillin resistant by testing for methicillin susceptibility and by PCR detection of the mecA gene.

The organotin compounds were tested in vitro for the antibacterial activity against clinical pathogen and reference strains using the disk diffusion test, in accordance with the procedures outlined by CLSI (formerly the NCCLS) [17]. Muller-Hinton agar was used for this method. Inocula were adjusted to $1.5 \times 10^{8} \mathrm{CFU} \mathrm{mL}$ (0.5 McFarland). BD BBLTM Sensi-Discs (Becton Dickinson and Company, Sparks, MD, USA) were used as growth inhibition controls. The antibiotics tested were Kanamycin $(30 \mu \mathrm{g})$, Vancomycin $(30 \mu \mathrm{g})$, Chloranphenicol (30 $\mu \mathrm{g})$, Cloxacillin (1 $\mu \mathrm{g})$, and Penicillin (10 IU).

The degree of effectiveness was measured by determining the diameters of the zone of inhibition caused by the compound. Compounds (1-5) were used, each one with a concentration of $6 \mathrm{mg}$ per disc. The plates were incubated at $37^{\circ} \mathrm{C}$ for $24 \mathrm{~h}$. During incubation time the complexes diffused from the disc to the medium. Effectiveness was classified into four different categories based on diameter of the zone of inhibition: $(+++)$ most effective, $(++)$ moderate effective, $(+)$ slightly effective, and $(-)$ noneffective. The results were compared against those of controls, which were screened simultaneously. The determinations were performed by triplicate and the results are reported as average values.

\section{Results and Discussion}

3.1. Synthesis. Compounds 1-5 are prepared by in situ condensation of L-histidine with 3,5-di-tert-butyl-2hydroxybenzaldehyde in the presence of the corresponding tin(IV) derivatives: di- $n$-methyltin oxide, di- $n$-butyltin oxide, di- $n$-phenyltin oxide, bis-tri- $n$-butyltin oxide, or triphenyltin hydroxide. These conditions affording compounds 1, 2, 3, 4, and 5, respectively, and the proposed structures are shown in Figure 1. In all complexes, the Schiff base histidine derivative is coordinated to the alkyl- or aryl-tin(IV) ion through the oxygen atom belonging to the carboxylate group. Compounds 1, 2, and 3 are also coordinated to the Schiff derivative through the imino nitrogen and the phenolic oxygen in order to stabilize a 5-coordinated tin(IV) core. In compounds 4 and $\mathbf{5}$, tin is 4 -coordinated.

All complexes are light yellow crystalline solids which are stable in air. Most of them are soluble in organic solvents. Compound 5 shows a very limited solubility in ethanol. Empirical formulae and proposed structures for all the compounds are confirmed by analytical and spectral data which are described in the following lines.

3.2. Infrared Spectroscopy. The coordination sphere on compounds 1-5 has been analyzed by means of FT-IR. The binding mode of the L-histidine Schiff base derivative to 

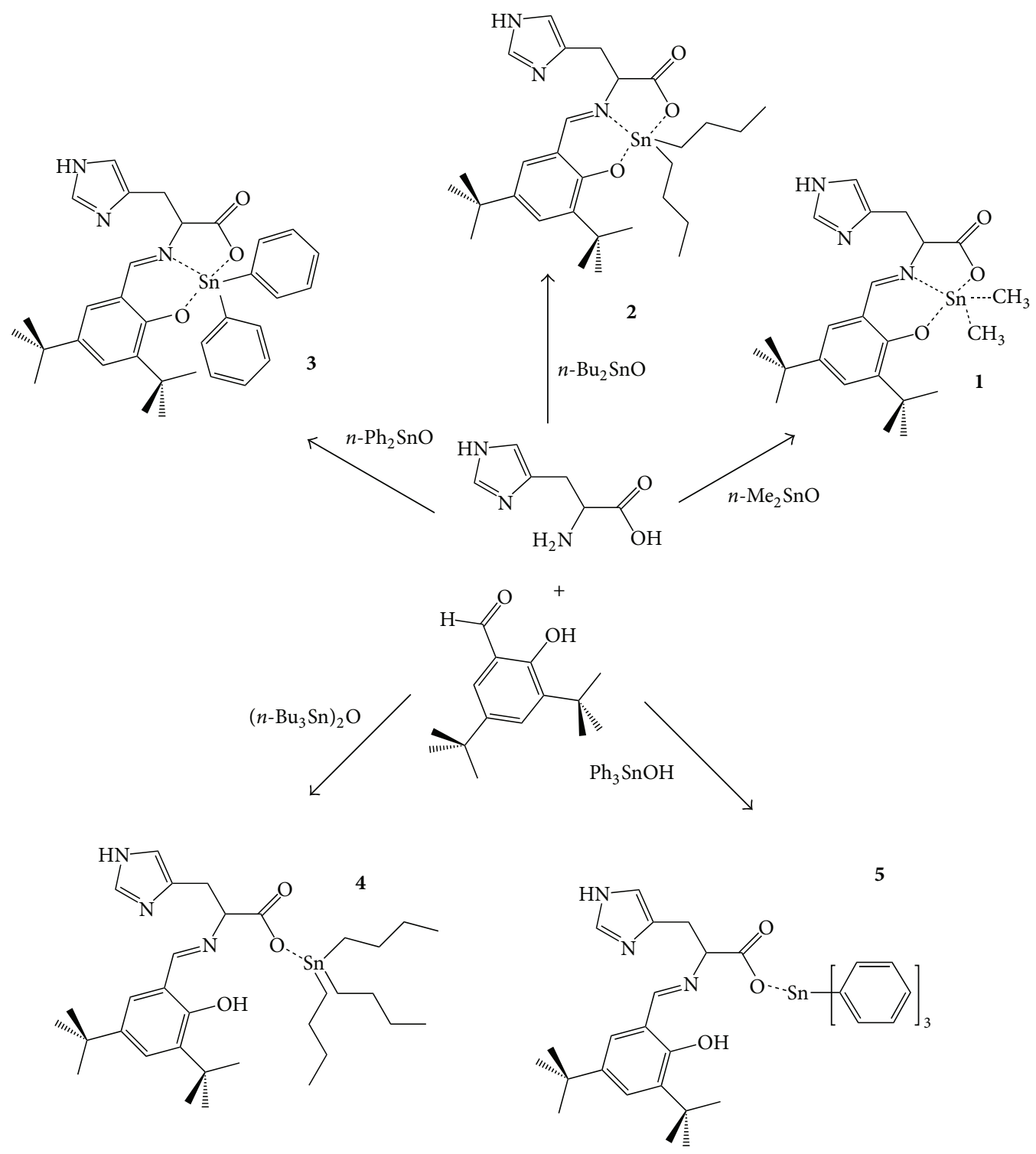

FIGURE 1: Schematic representation of compounds 1-5 and their synthetic procedure.

metal in the complexes has been studied by comparison of IR spectra of free ligand precursors and metal complexes. The absence of the broad $\mathrm{O}-\mathrm{H}$ stretching frequencies in the region $3170-2870 \mathrm{~cm}^{-1}$ denotes that deprotonation and coordination of the carboxylate group to tin have taken part during the complex formation in all compounds.

Free L-histidine shows a strong band at $1630 \mathrm{~cm}^{-1}$, which is assigned to the stretching vibration of the $\mathrm{C}=\mathrm{O}$ bond. There are also medium strength bands at $1589-1571 \mathrm{~cm}^{-1}$ that are assigned to the $\mathrm{C}=\mathrm{N}$ and $\mathrm{C}=\mathrm{C}$ stretching vibration. The corresponding bands in the tin compounds are shifted to higher frequencies as expected, due to tin coordination. For pentacoordinated compounds 1, 2, and 3, the observed shifts are in the range $40-30 \mathrm{~cm}^{-1}$. For tetracoordinated tin compounds $\mathbf{4}$ and $\mathbf{5}$, the shifts are smaller in the range 11$2 \mathrm{~cm}^{-1}$. This observation is compatible with some other 4coordinated structures described in the literature $[9,18]$.
Moreover, the azomethine band is easily observed at 1539$1538 \mathrm{~cm}^{-1}$ region for compounds $\mathbf{1}, \mathbf{2}$, and 3 . This red shift is considered the result of coordination of this moiety to the metal center (see Figure 1) [6]. For compounds 4 and 5, this $v(\mathrm{C}=\mathrm{N})$ band is not observed in such region, evidence that demonstrates that the azomethine moiety is not involved in coordination to tin.

The carboxylate moiety in compounds $\mathbf{1}-\mathbf{5}$ has been structurally characterized by the intense and broad absorptions in the range $1660-1330 \mathrm{~cm}^{-1}$, due to asymmetric and symmetric stretching modes. The difference between asymmetric and symmetric $\mathrm{O}-\mathrm{C}=\mathrm{O}$ stretching vibrations $(\Delta \nu)$ has been used to determine the mode of coordination of a carboxylate ligand with metals $[9,19,20]$. Differences larger than $250 \mathrm{~cm}^{-1}$ are indicative of monodentate carboxylate complexes, while $\Delta v$ values in the range $150-250 \mathrm{~cm}^{-1}$ are indicative of compounds with carboxylate-bridged structures. Finally, it is 
presumed that a chelation is present, if this parameter is lower than $150 \mathrm{~cm}^{-1}$.

The $\Delta v=v_{\text {as }}(\mathrm{OCO})-v_{\mathrm{s}}(\mathrm{OCO})$ for the proposed pentacoordinated compounds $\mathbf{1}, \mathbf{2}$, and $\mathbf{3}$ is the following: $\Delta v$ $=297,305$, and $307 \mathrm{~cm}^{-1}$, respectively. For the tetracoordinated compounds 4 and $\mathbf{5}, \Delta v$ is $\Delta v=245$ and $270 \mathrm{~cm}^{-1}$, respectively. All values of $\Delta \nu$ for compounds $\mathbf{1 - 5}$ are in the range $310-245 \mathrm{~cm}^{-1}$, and this evidence strongly suggests that the carboxylate group in all compounds adopted a unidentate nature.

Some other stretching frequencies of interest are those characteristics of the $\nu(\mathrm{Sn}-\mathrm{C}), \nu(\mathrm{Sn}-\mathrm{O})$, and $\nu(\mathrm{Sn}-\mathrm{N})$ bonds frequencies. All these values are consistent with those detected in a number of organotin(IV)-oxygen, organotin(IV)-carbon, and organotin(IV)-nitrogen derivatives $[10,21,22]$. Worthy mentioning is the presence of two $\nu(\mathrm{Sn}-\mathrm{O})$ weak bond frequencies for compounds 1 (655, $\left.623 \mathrm{~cm}^{-1}\right), 2\left(655,622 \mathrm{~cm}^{-1}\right)$, and $3\left(654,620 \mathrm{~cm}^{-1}\right)$ [23]. This evidence could be explained in views of two different $\mathrm{Sn}-\mathrm{O}$ bonds. Compounds $\mathbf{4}$ and $\mathbf{5}$ only show one stretching $\mathrm{Sn}-\mathrm{O}$ vibration. Then it suggests that just one type of $\mathrm{Sn}-\mathrm{O}$ bond is observed, confirming the tetracoordinated sphere for tin in the compounds.

The recorded high-resolution mass spectra of 1-5 and molecular ion peaks are in agreement with the proposed structures. The MS peaks present the correct isotopomer distribution, as expected for the tin isotope distribution.

For instance, in complex $\mathbf{1}$, the degradation pattern shows peaks at $520(100 \% \mathrm{~m} / z)$ that indicates molecular ion peak $\left[\mathrm{M}^{+},\left[\left(\mathrm{C}_{21} \mathrm{H}_{28} \mathrm{~N}_{3} \mathrm{O}_{3}\right) \mathrm{Sn}\left(\mathrm{CH}_{3}\right)_{2}\right]^{+}\right]$, whereas peaks at 542 $(16 \% \mathrm{~m} / z)$ and $1037(7 \% \mathrm{~m} / \mathrm{z})$ show $3\left[\mathrm{M}^{+}\right]+\mathrm{CH}_{2} \mathrm{Cl}_{2}$ and $\left[\mathrm{M}^{+}\right]+\mathrm{M}$, respectively (Figure 2 ). Complex 2 shows the normal trends of degradation patterns (Figure 3). The various degradation peaks at $604(100 \% \mathrm{~m} / z)$ show molecular ion; the peaks at $625(11 \% \mathrm{~m} / z)$ show $4\left[\mathrm{M}^{+}\right]+\mathrm{CH}_{2} \mathrm{Cl}_{2}$; peaks at 1205 $(3 \% \mathrm{~m} / z)$ show $\left[\mathrm{M}^{+}\right]+\mathrm{M}$.

Complexes 3-5 again show a similar pattern of degradation.

3.3. Multinuclear NMR Spectroscopy. The ${ }^{1} \mathrm{H},{ }^{13} \mathrm{C}$, and ${ }^{119} \mathrm{Sn}$ NMR spectra of compounds $\mathbf{1 - 4}$ have been recorded in $\mathrm{CDCl}_{3}$ or $\mathrm{MeOD}$ and the assignments obtained through $1 \mathrm{D}$ and $2 \mathrm{D}$ experiments. When necessary, ${ }^{119} \mathrm{Sn}$ NMR spectra have also been recorded in the solid state. The very limited solubility of compound 5 prompted us to obtain the ${ }^{13} \mathrm{C}$ and ${ }^{119} \mathrm{Sn}$ spectra in the solid state only.

The ${ }^{1} \mathrm{H}$ NMR spectra assignment of compounds 1-5 is based on integration values, chemical shifts, coupling constants, and ${ }^{1} \mathrm{H}^{-13} \mathrm{C}$ HMQC experiments. Starting and model compounds spectra were also useful for comparison reasons [18]. The expected resonances are observed for L-histidine, 3,5-di-tert-butyl2-hydroxybenzaldehyde, tributyltin(IV), triphenyltin(IV), dibutyltin(IV), dimethyltin(IV), and dibutyltin(IV) moieties. Due to rapid exchange between the two nitrogen atoms of the imidazole ring and probably with deuterium from solvent, the $\mathrm{N}-\mathrm{H}$ proton from the imidazole moiety is not observed in the spectra.
The results obtained are listed in Tables 1 and 2. For comparative purposes the data are tabulated using a general numbering scheme (Figure 4).

The characteristic resonance peak in the ${ }^{1} \mathrm{H}$ NMR spectra of compounds 1-5, at 8.4-7.9 ppm, reveals the presence of the imino moiety $\mathrm{H}-\mathrm{C} 11=\mathrm{N}$, which confirms the condensation of the L-histidine derivative (Figure 1). Additionally, for compounds $\mathbf{1}, \mathbf{2}$, and $\mathbf{3}$, coordination to Sn(IV) is confirmed by small coupling peaks associated to the $\mathrm{H}-\mathrm{Cl1}=\mathrm{N}$ resonance peak. This spin-spin coupling between the azomethine proton and the tin nucleus, ${ }^{3} \mathrm{~J}(\mathrm{Sn}-\mathrm{N}=\mathrm{CH})$, presents coupling constants in the range $52-70 \mathrm{ppm}$, values that are in agreement with a magnetic coupling between the tin nuclei located in a transposition with respect to the azomethine proton $[23,24]$. In complex $\mathbf{1}$, characteristic peaks of the methyl groups attached to the tin atom are observed at 0.64 and $0.56 \mathrm{ppm}$ as expected [25]. In complex 2 , the presence of the $\mathrm{Sn}-\mathrm{Bu}_{2}$ resonance peaks, $\mathrm{H} \alpha, \mathrm{H} \beta, \mathrm{H} \gamma$, and $\mathrm{H} \delta$, confirms the chemical nature of the dibutyl moiety of 2 . In compound 4 , the butyl protons appear in the range $0.80-1.53 \mathrm{~cm}^{-1}$, with multiplicity and integration values in agreement with the proposed structure. For complex $\mathbf{3}$ the signals corresponding to the phenyl groups are clearly observed.

The ${ }^{1} \mathrm{H}$ NMR spectra of all the complexes present a resonance peak assigned to $\mathrm{H}-\mathrm{C} 12$ moiety. This moiety is attached to the carboxylic group and it is observed in the range $4.14-4.59 \mathrm{ppm}$. These are clearly downfield shifted when comparing with the resonance peak in the free ligand at around $3.98 \mathrm{ppm}\left(\mathrm{D}_{2} \mathrm{O}\right)$. This evidence suggests that the downfield effect is due to coordination to tin. In this order of ideas, the ${ }^{1} \mathrm{H}$ NMR spectra of all complexes present a resonance for $\mathrm{H}-\mathrm{C} 14$ with the same downfield shift effect (3.15-3.47), with a minimal shift for compounds 3 and $\mathbf{4}$. The signals corresponding to the tert-butyl protons of the ligand have also been assigned and all data is presented in Table 1.

Table 2 presents the ${ }^{13} \mathrm{C}$ NMR and ${ }^{119} \mathrm{Sn}$ NMR data for the synthesized organotin compounds following the same numbering scheme presented on Figure 4. The very limited solubility of compound 5 prompted us to obtain the ${ }^{13} \mathrm{C}$ and ${ }^{119} \mathrm{Sn}$ spectra in the solid state. The ${ }^{13} \mathrm{C}$ NMR characterization was obtained through comparison with starting materials, and structural related analogues.

The ${ }^{13} \mathrm{C}$ NMR data explicitly resolved the resonances of all the distinct carbon atoms present in all the complexes. The ${ }^{13} \mathrm{C}$ NMR data for all compounds show that the resonance peak of the carboxyl carbon, C13, appears in the range from 173 to $177 \mathrm{ppm}$, in agreement with the data reported for analogous derivatives [18]. The signal of the imine carbon, C11, appears in the 166-177 ppm range, showing in some cases a marked deshielding effect with respect to the imine group. The $\mathrm{Sn}-\mathrm{N}$ coordination should produce an $\mathrm{N}-\mathrm{C}$ polarization. The biggest polarization effect could be observed, as expected, in compound $\mathbf{3}$ where phenyl groups are attached to tin.

For compounds 4 and $\mathbf{5}$, the signal of the imine carbon, C11, appears in the range $165-167 \mathrm{ppm}$, which is consistent with the lack of the $\mathrm{Sn}-\mathrm{N}$ coordination. The same high field shift effect could be observed in case of $\mathrm{C} 2$. 


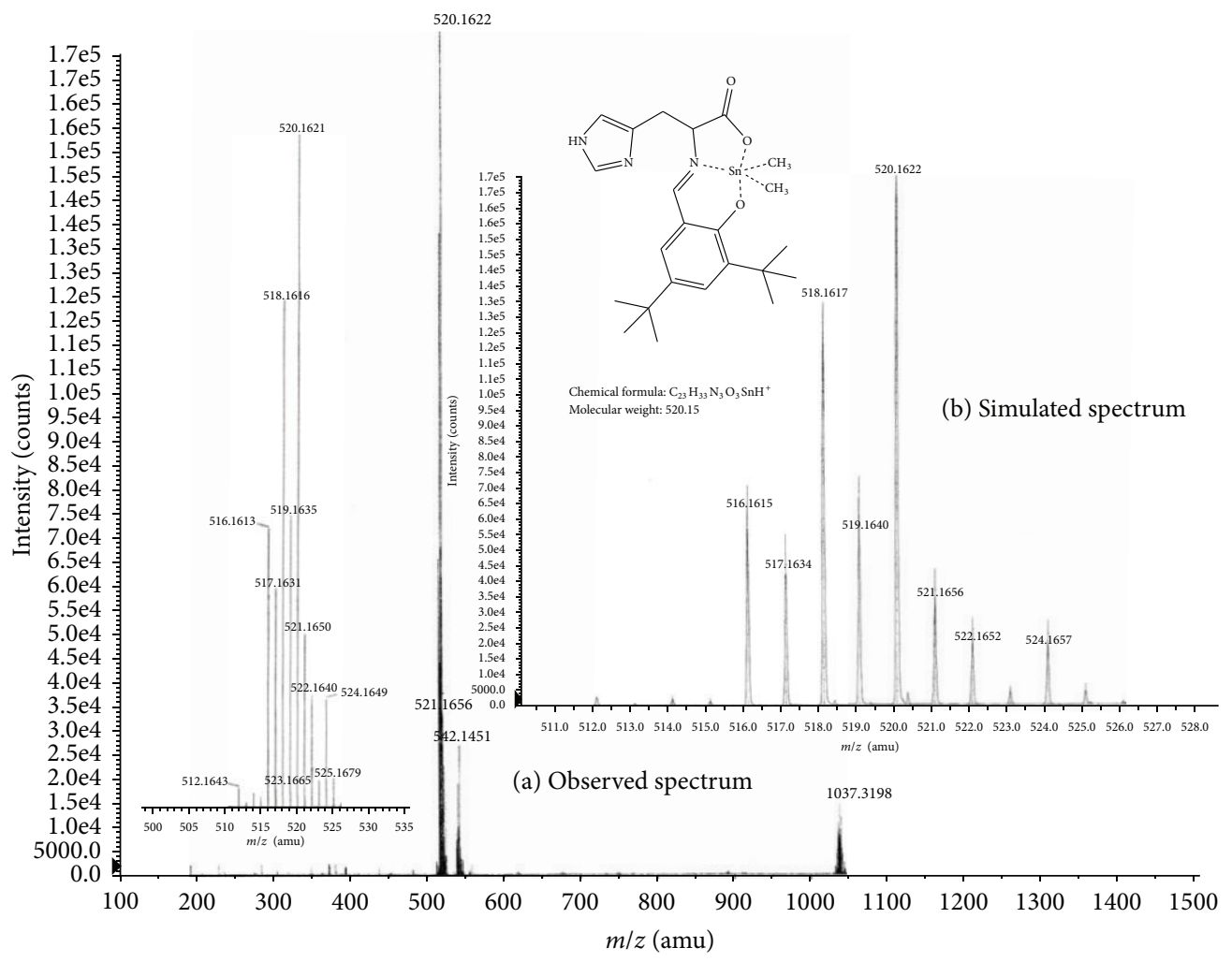

Figure 2: Observed mass spectrum (a) and simulated spectrum (b) of complex 1.

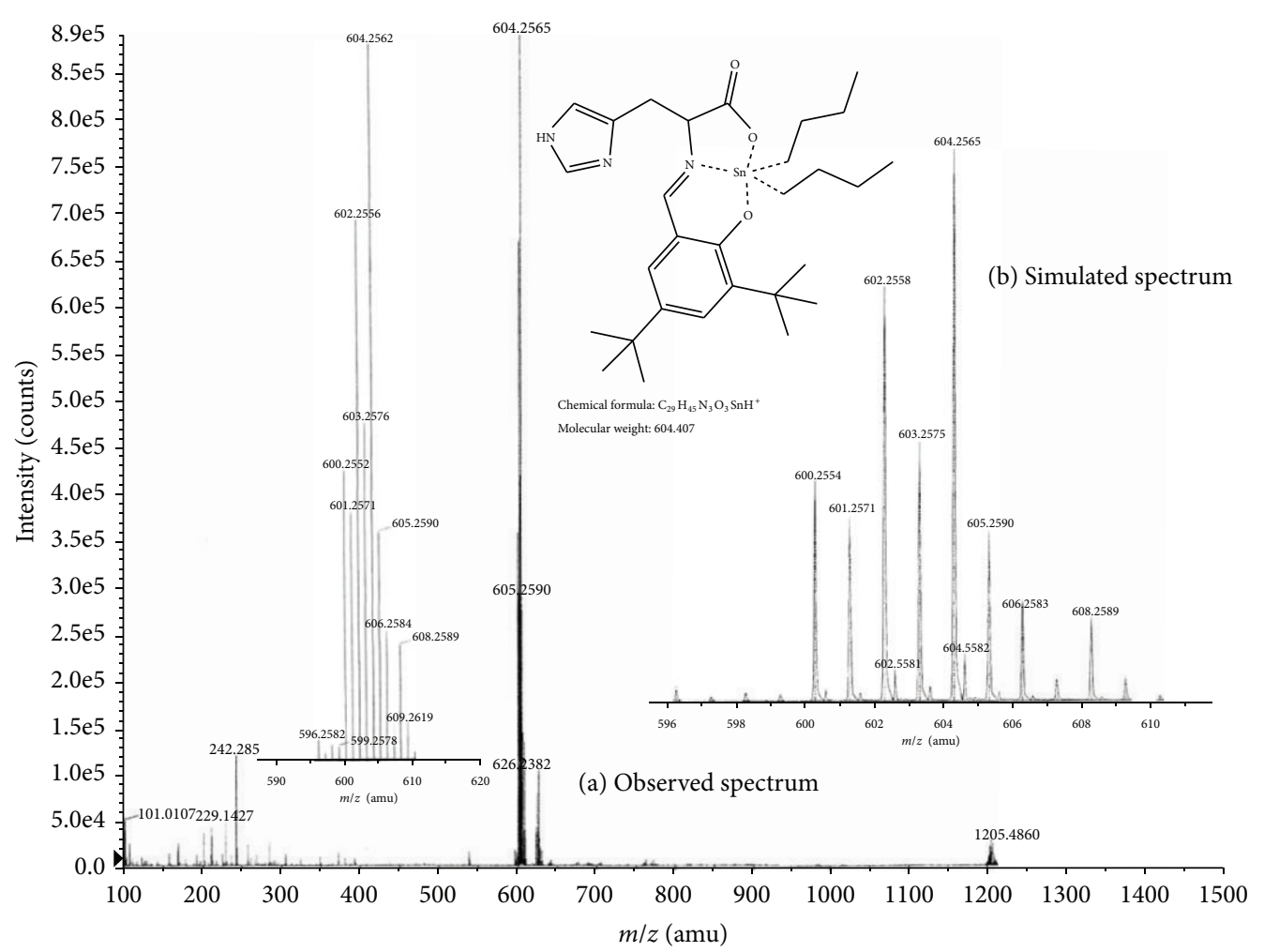

FIGURE 3: Observed mass spectrum (a) and simulated spectrum (b) of complex 2. 

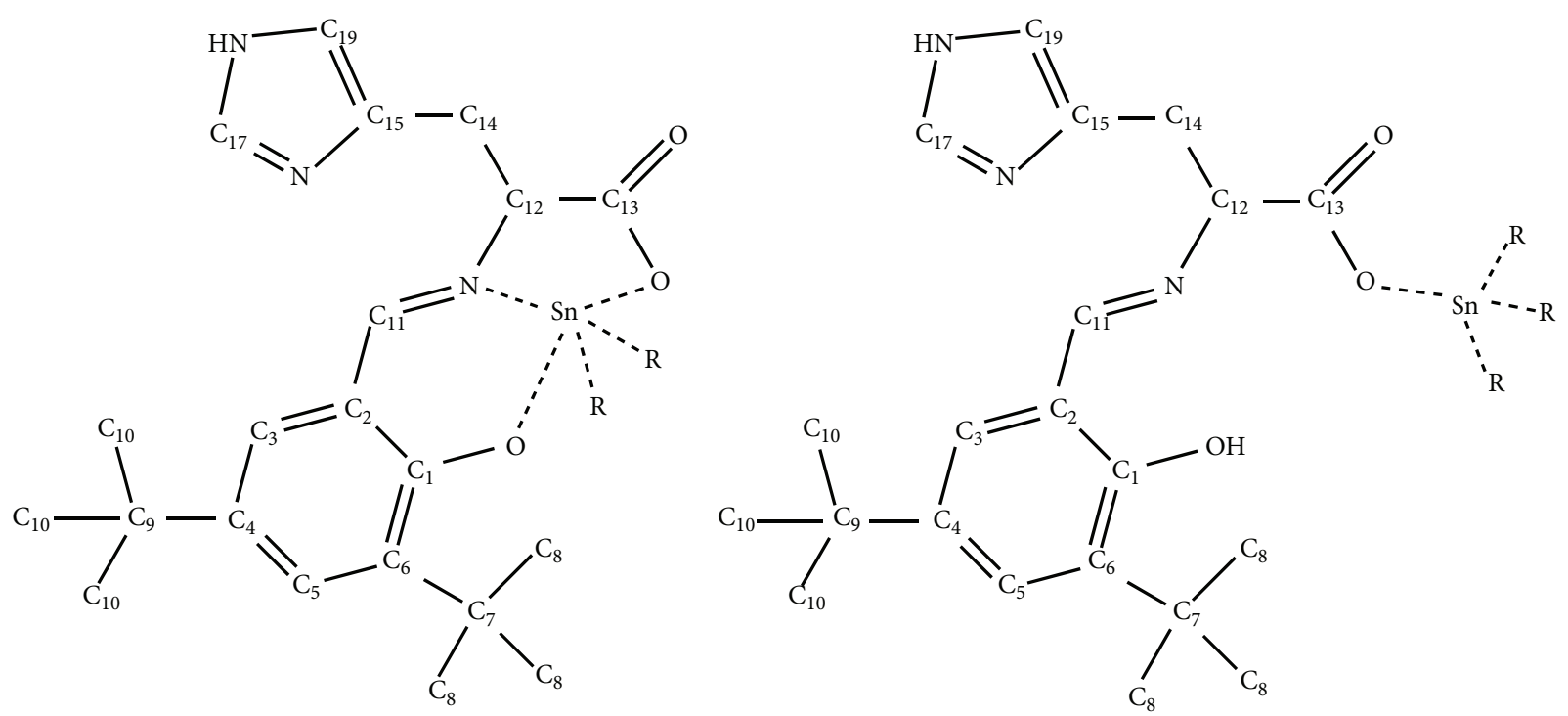

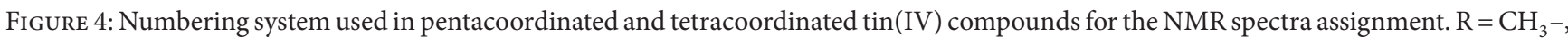
$\mathrm{CH}_{3} \mathrm{CH}_{2} \mathrm{CH}_{2} \mathrm{CH}_{2}-(\mathrm{CH} \alpha, \mathrm{CH} \beta, \mathrm{CH} \gamma, \mathrm{CH} \delta)$ or $\mathrm{C}_{6} \mathrm{H}_{5}-(\mathrm{CHo}, \mathrm{CHm}, \mathrm{CHp})$.

TABLE 1: ${ }^{1} \mathrm{H}$ NMR data of compounds $\mathbf{1 - 5}$.

\begin{tabular}{|c|c|c|c|c|}
\hline Compound numbering & $\begin{array}{c}\mathbf{1} \\
\mathrm{CDCl}_{3} \\
\end{array}$ & $\begin{array}{c}2 \\
\mathrm{CDCl}_{3} \\
\end{array}$ & $\begin{array}{c}3 \\
\mathrm{CD}_{3} \mathrm{OD}\end{array}$ & $\begin{array}{c}\mathbf{4} \\
\mathrm{CDCl}_{3} \\
\end{array}$ \\
\hline H11 & $8.13(\mathrm{~s}, 1 \mathrm{H})[58]$ & $7.91(\mathrm{~s}, 1 \mathrm{H})[52]$ & $8.33(\mathrm{~s}, 1 \mathrm{H})[70]$ & $8.34(\mathrm{~s}, 1 \mathrm{H})$ \\
\hline H17 & $7.63(\mathrm{~s}, 1 \mathrm{H})$ & $7.60(\mathrm{~s}, 1 \mathrm{H})$ & $7.08(\mathrm{~s}, 1 \mathrm{H})$ & $7.48(\mathrm{~s}, 1 \mathrm{H})$ \\
\hline H5 & $7.54(\mathrm{~d}, 1 \mathrm{H})[2.4]$ & $7.51(\mathrm{~d}, 1 \mathrm{H})[2.7]$ & $7.63(\mathrm{~d}, 1 \mathrm{H})[2.4]$ & $7.35(\mathrm{~d}, 1 \mathrm{H})[2.4]$ \\
\hline H3 & $6.85(\mathrm{~d}, 1 \mathrm{H})[2.4]$ & $6.76(\mathrm{~d}, 1 \mathrm{H})[2.7]$ & $7.07(\mathrm{~d}, 1 \mathrm{H})[2.5]$ & $7.03(\mathrm{~d}, 1 \mathrm{H})[2.4]$ \\
\hline H19 & $6.80(\mathrm{~s}, 1 \mathrm{H})$ & $6.73(\mathrm{~s}, 1 \mathrm{H})$ & $6.52(\mathrm{~s}, 1 \mathrm{H})$ & $6.73(\mathrm{~s}, 1 \mathrm{H})$ \\
\hline H12 & $4.43(\mathrm{~m}, 1 \mathrm{H})$ & $4.43(\mathrm{~m}, 1 \mathrm{H})$ & $4.59(\mathrm{~m}, 1 \mathrm{H})$ & $4.14(\mathrm{~m}, 1 \mathrm{H})$ \\
\hline H14 & $\begin{array}{c}3.39-3.25 \\
(\mathrm{~m}, 2 \mathrm{H})\end{array}$ & $\begin{array}{c}3.47-3.44 \\
3.11-3.07(\mathrm{~m}, 2 \mathrm{H})\end{array}$ & $\begin{array}{c}3.27-3.16 \\
(\mathrm{~m}, 2 \mathrm{H})\end{array}$ & $\begin{array}{l}3.31-3.15 \\
(\mathrm{~m}, 2 \mathrm{H})\end{array}$ \\
\hline $\mathrm{H} \gamma$ & & $\begin{array}{c}1.73-1.51 \\
(\mathrm{~m}, 4 \mathrm{H})\end{array}$ & & $\begin{array}{c}1.27-1.28 \\
(\mathrm{~m}, 6 \mathrm{H})\end{array}$ \\
\hline $\mathrm{H} \alpha$ & & $1.4-1.3(\mathrm{~m}, 4 \mathrm{H})$ & & $1.27-1.28(\mathrm{~m}, 6 \mathrm{H})$ \\
\hline $\mathrm{H} \beta$ & & $1.4-1.3(\mathrm{~m}, 4 \mathrm{H})$ & & $\begin{array}{c}1.53 \\
(\mathrm{~m}, 6 \mathrm{H})\end{array}$ \\
\hline $\mathrm{H} \delta$ & & $\begin{array}{l}0.92(\mathrm{t}, 3 \mathrm{H})[7.3] \\
0.79(\mathrm{t}, 3 \mathrm{H})[7.3]\end{array}$ & & $0.80(\mathrm{t}, 9 \mathrm{H})[7.3]$ \\
\hline Ho & & & $\begin{array}{c}7.87-7.82 \\
(\mathrm{~m}, 4 \mathrm{H})\end{array}$ & \\
\hline $\mathrm{Hm}$ & & & $\begin{array}{c}7.58-7.29 \\
(\mathrm{~m}, 4 \mathrm{H})\end{array}$ & \\
\hline Hp & & & $\begin{array}{c}7.58-7.29 \\
(\mathrm{~m}, 4 \mathrm{H})\end{array}$ & \\
\hline $\begin{array}{l}\mathrm{H} 8, \mathrm{H} 10 \\
\text { t-butyl } \mathrm{CH}_{3}\end{array}$ & $\begin{array}{l}1.37(\mathrm{~s}, 9 \mathrm{H}) \\
1.28(\mathrm{~s}, 9 \mathrm{H})\end{array}$ & $\begin{array}{l}1.37(\mathrm{~s}, 9 \mathrm{H}) \\
1.25(\mathrm{~s}, 9 \mathrm{H})\end{array}$ & $\begin{array}{l}1.47(\mathrm{~s}, 9 \mathrm{H}) \\
1.30(\mathrm{~s}, 9 \mathrm{H})\end{array}$ & $\begin{array}{l}1.41(\mathrm{~s}, 9 \mathrm{H}) \\
1.28(\mathrm{~s}, 9 \mathrm{H})\end{array}$ \\
\hline $\mathrm{CH}_{3}-\mathrm{Sn}$ & $\begin{array}{l}0.64(\mathrm{~s}, 6 \mathrm{H}), \\
0.56(\mathrm{~s}, 6 \mathrm{H})\end{array}$ & & & \\
\hline
\end{tabular}

Data obtained at $500 \mathrm{MHz}$. Chemical shifts in ppm with respect to TMS; coupling constants in hertz, ${ }^{n} J\left({ }^{1} \mathrm{H}-{ }^{1} \mathrm{H}\right)$ and ${ }^{n} J\left({ }^{1} \mathrm{H}-{ }^{119 / 117} \mathrm{Sn}\right)$ between brackets. s: singlet; d: doublet; t: triplet; m: complex pattern. Assignment base in 1D and 2D NMR studies. 
TABLe $2:{ }^{13} \mathrm{C}$ and ${ }^{119} \mathrm{Sn}$ NMR data of compounds $\mathbf{1}-\mathbf{5}$.

\begin{tabular}{|c|c|c|c|c|c|}
\hline Compound numbering & $\begin{array}{c}1 \\
\mathrm{CDCl}_{3} \\
\end{array}$ & $\begin{array}{c}2 \\
\mathrm{CDCl}_{3} \\
\end{array}$ & $\begin{array}{c}3 \\
\mathrm{CD}_{3} \mathrm{OD}\end{array}$ & $\begin{array}{c}\mathbf{4} \\
\mathrm{CDCl}_{3} \\
\end{array}$ & $\begin{array}{c}\mathbf{5} \\
\text { Solid state } \\
\end{array}$ \\
\hline C11 & 174.33 & 174.54 & 177.66 & 167.57 & 166.6 \\
\hline $\mathrm{C} 13$ & 173.72 & 173.72 & 175.79 & 175.62 & 176.6 \\
\hline $\mathrm{C} 2$ & 166.59 & 167.0 & 168.61 & 158.13 & 157.55 \\
\hline $\mathrm{C} 1$ & 141.29 & 140.96 & 143.61 & 140.00 & a \\
\hline $\mathrm{C} 4$ & 139.04 & 138.64 & 142.00 & 136.67 & a \\
\hline C6 & 135.70 & 135.67 & 134.63 & 134.09 & a \\
\hline C5 & 133.19 & 133.08 & 132.97 & 127.16 & a \\
\hline $\mathrm{C} 17$ & $131.08(b)$ & $131.30(\mathrm{~b})$ & $132.64(b)$ & $131.98(b)$ & - \\
\hline $\mathrm{C} 3$ & 129.49 & 129.47 & 129.95 & 126.24 & $\mathrm{a}$ \\
\hline $\mathrm{C} 19$ & 119.78 (b) & $119.84(b)$ & $118.00(b)$ & 123.69 (b) & 120.2 \\
\hline $\mathrm{C} 15$ & 116.61 & 116.51 & 119.66 & 117.98 & 117.5 \\
\hline $\mathrm{C} 12$ & 67.18 & 67.42 & 68.56 & 72.02 & 64.0 \\
\hline $\mathrm{C} 7$ & 35.27 & 35.19 & 35.45 & 35.08 & 34.68 \\
\hline C9 & 34.06 & 33.93 & 34.17 & 34.16 & 33.86 \\
\hline $\mathrm{C} 14$ & 33.97 & $33.90(b)$ & 33.98 & $29.50(b)$ & 29.5 \\
\hline $\mathrm{C} 8$ & 31.23 & 31.10 & 30.56 & 31.54 & 31.0 \\
\hline $\mathrm{C} 10$ & 29.44 & 29.36 & 29.47 & 29.50 & 29.2 \\
\hline $\mathrm{CH}_{3}$ & $\begin{array}{l}1.23,0.933 \\
{[653 / 648]}\end{array}$ & & & & \\
\hline $\mathrm{C}_{\beta}$ & & $\begin{array}{c}27.00 \text { [38] } \\
26.85 \text { [n.o.] }\end{array}$ & & $28.07[24]$ & \\
\hline $\mathrm{C}_{\gamma}$ & & $\begin{array}{l}26.74[91] \\
26.56[92]\end{array}$ & & $27.02[72 / 70]$ & \\
\hline $\mathrm{C}_{\alpha}$ & & $\begin{array}{l}22.26[599] \\
22.20[599]\end{array}$ & & $17.73[435 / 415]$ & \\
\hline $\mathrm{C}_{\delta}$ & & $\begin{array}{l}13.59 \\
13.39\end{array}$ & & 13.66 & \\
\hline $\mathrm{C}_{\mathrm{i}}$ & & & $\begin{array}{l}142.67 \text { [n.o.] } \\
141.27 \text { [n.o.] }\end{array}$ & & $\mathrm{a}$ \\
\hline $\mathrm{C}_{\mathrm{o}}$ & & & $\begin{array}{l}137.78[53] \\
137.32[53]\end{array}$ & & a \\
\hline $\mathrm{C}_{\mathrm{m}}$ & & & $\begin{array}{l}130.54[87] \\
130.23[83]\end{array}$ & & $\mathrm{a}$ \\
\hline $\mathrm{C}_{\mathrm{p}}$ & & & $\begin{array}{c}132.12 \text { [n.o.] } \\
131.64 \text { [16] }\end{array}$ & & a \\
\hline${ }^{119} \mathrm{Sn}$ & $\begin{array}{l}-162.16 \\
\mathrm{CDCl}_{3}\end{array}$ & $\begin{array}{l}-197.58 \\
\mathrm{CDCl}_{3}\end{array}$ & $\begin{array}{c}-369 \\
\mathrm{CD}_{3} \mathrm{OD}\end{array}$ & $\begin{array}{r}39.44 \\
\mathrm{CDCl}_{3}\end{array}$ & No soluble \\
\hline $\begin{array}{l}{ }^{119} \mathrm{Sn} \\
\text { Solid state }\end{array}$ & -169.50 & -196.68 & -455.87 & -112.59 & -122.09 \\
\hline
\end{tabular}

Chemical shifts in ppm with respect to TMS; ${ }^{119} \mathrm{Sn}$ chemical shifts in ppm with respect to $\left(\mathrm{CH}_{3}\right)_{4} \mathrm{Sn} ;{ }^{n} \mathrm{~J}\left({ }^{13} \mathrm{C}-{ }^{119 / 117} \mathrm{Sn}\right)$ coupling constants between square brackets. n.o.: not observed.

a: Unambiguous assignment of this resonance peak was not reached because there are multiple broad signals included in the range 143-127 ppm.

The ${ }^{1} J\left({ }^{13} \mathrm{C}-{ }^{117 / 119} \mathrm{Sn}\right)$ coupling constant values are of major importance in the estimation of the coordination mode of the tin atom. The values of ${ }^{1} J$ (in solution) can be related to the tin-coordination number. Thus these values are a qualitative evidence of the organotin(IV) compound structure [2628]. Pentacoordinated organotin(IV) ions show ${ }^{1} J$ values between $450-610 \mathrm{~Hz}$, while tetracoordinated organotin(IV) ions show values in the range $325-440 \mathrm{~Hz}$ [18].

The ${ }^{1} J$ coupling constants for compounds 1 and 2 suggest a pentacoordinated nature in solution. For compound 3 the ${ }^{1} J$ coupling constants are not observed. For compound 4 the ${ }^{1} J$ values are 415 and $435 \mathrm{~Hz}$, suggesting a four-coordinated 


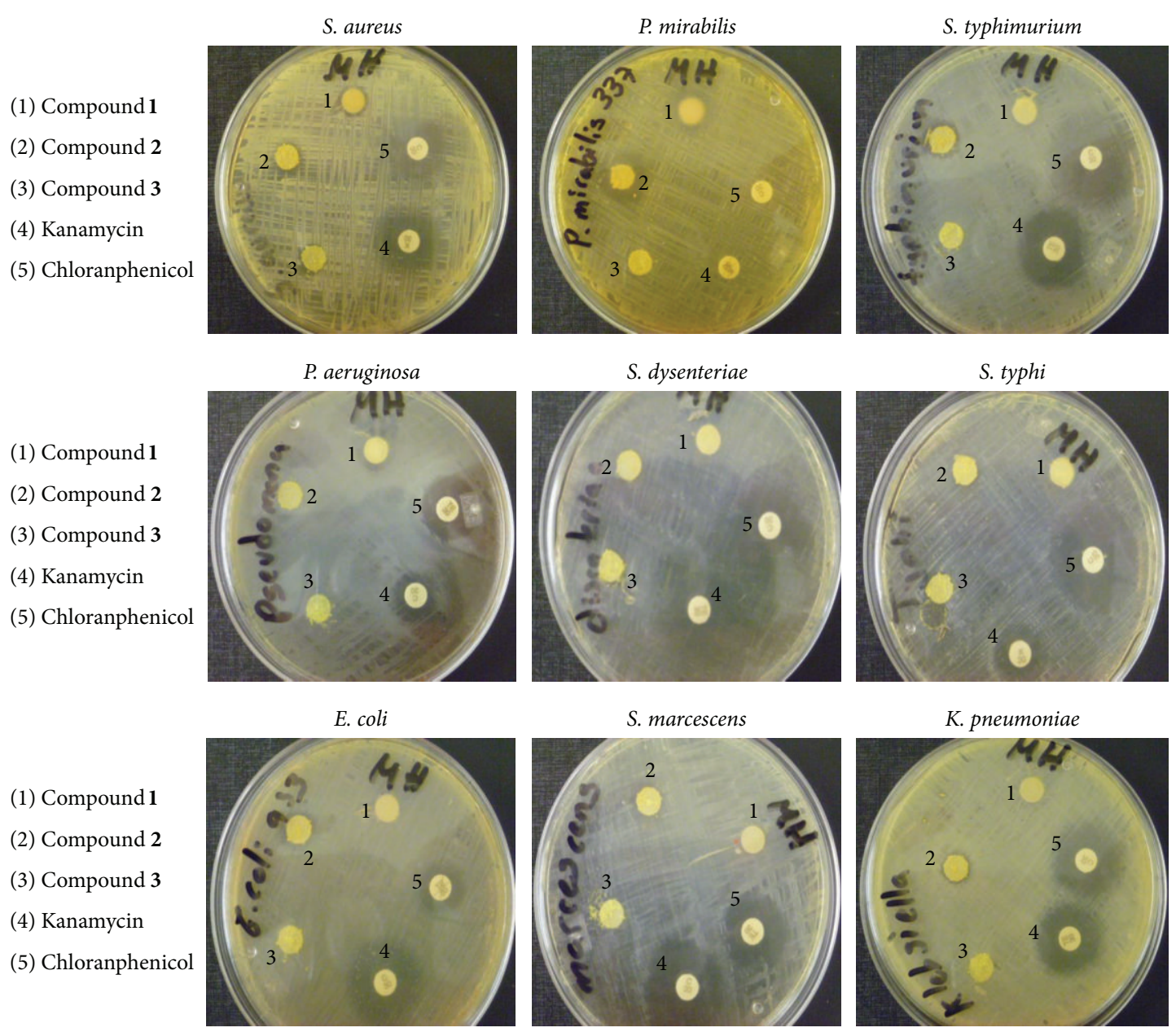

Figure 5: Photographs of the antimicrobial activities of compounds 1, 2, and $\mathbf{3}$ against S. aureus, P. mirabilis, S. typhimurium, P. aeruginosa, S. dysenteriae, and S. typhi, showing their inhibition zone.

structure in solution. The ${ }^{2} J\left({ }^{13} \mathrm{C}-{ }^{117 / 119} \mathrm{Sn}\right)=72 / 70 \mathrm{~Hz}$ also suggests a tetrahedral geometry for 4 .

The correct assignment of ${ }^{13} \mathrm{C}$ NMR resonances of the $n$-butyl group in $\mathbf{2}$ is determined by the coupling constants ${ }^{n} J\left({ }^{13} \mathrm{C}-{ }^{117 / 119} \mathrm{Sn}\right)$. Compound 2 displays a resonance peak for the $n$-butyl $\mathrm{C} \alpha$ at $21-22$ ppm with two very close coupling signals. This observation provides additional evidence for the magnetic equivalence of the butyl moieties. The same criterion is followed in the assignment of ${ }^{13} \mathrm{C}$ NMR resonances of the $n$-butyl group in 4 . The magnetic equivalence of the butyl moieties is concluded from the spectra.

In order to provide further evidence for the proposed structures of the complexes in solution, ${ }^{119}$ Sn NMR spectra are analyzed. The ${ }^{119} \mathrm{Sn}$ chemical shifts are extremely dependent on the coordination number for tin and the nature of the groups directly coordinated to the metal. The chemical shift values for compounds $\mathbf{1 - 3}$ are within the expected range for pentacoordinated tin ions with a single resonance peak in solution. There are not changes in the solid state spectra as could be appreciated by the chemical shifts observed in the corresponding solid ${ }^{119}$ Sn NMR spectra. Thus, the structural composition in the solid state is retained in solution for compounds 1,2 , and 3 .

${ }^{119} \mathrm{Sn}$ NMR spectrum of compound 4 exhibits a single resonance in solution, with a chemical shift of $39.44 \mathrm{ppm}$. In the solid state, the chemical shift observed is characteristic of a five-coordinated compound. This evidence suggests that in the solid state inter- or intramolecular interactions could be responsible of the increase in coordination number.

No ${ }^{119} \mathrm{Sn}$ resonance could be observed for compound 5 in solution, due to its limited solubility. In addition the chemical shift observed in the ${ }^{119}$ Sn NMR spectrum in the solid state suggests the tetracoordinated nature of 5. Despite the Lewis acidity that a phenyl group could induce in the tin atom [29], this is very low as this compound appears unable to extent its coordination sphere.

3.4. Microbial Activities. Organotin(IV) cations with biological active ligands are a major research debt for the scientific efforts in the search of new metal-based drugs, but little work is available on the bactericidal properties of organotin(IV) derivatives of amino acids in the literature. In 


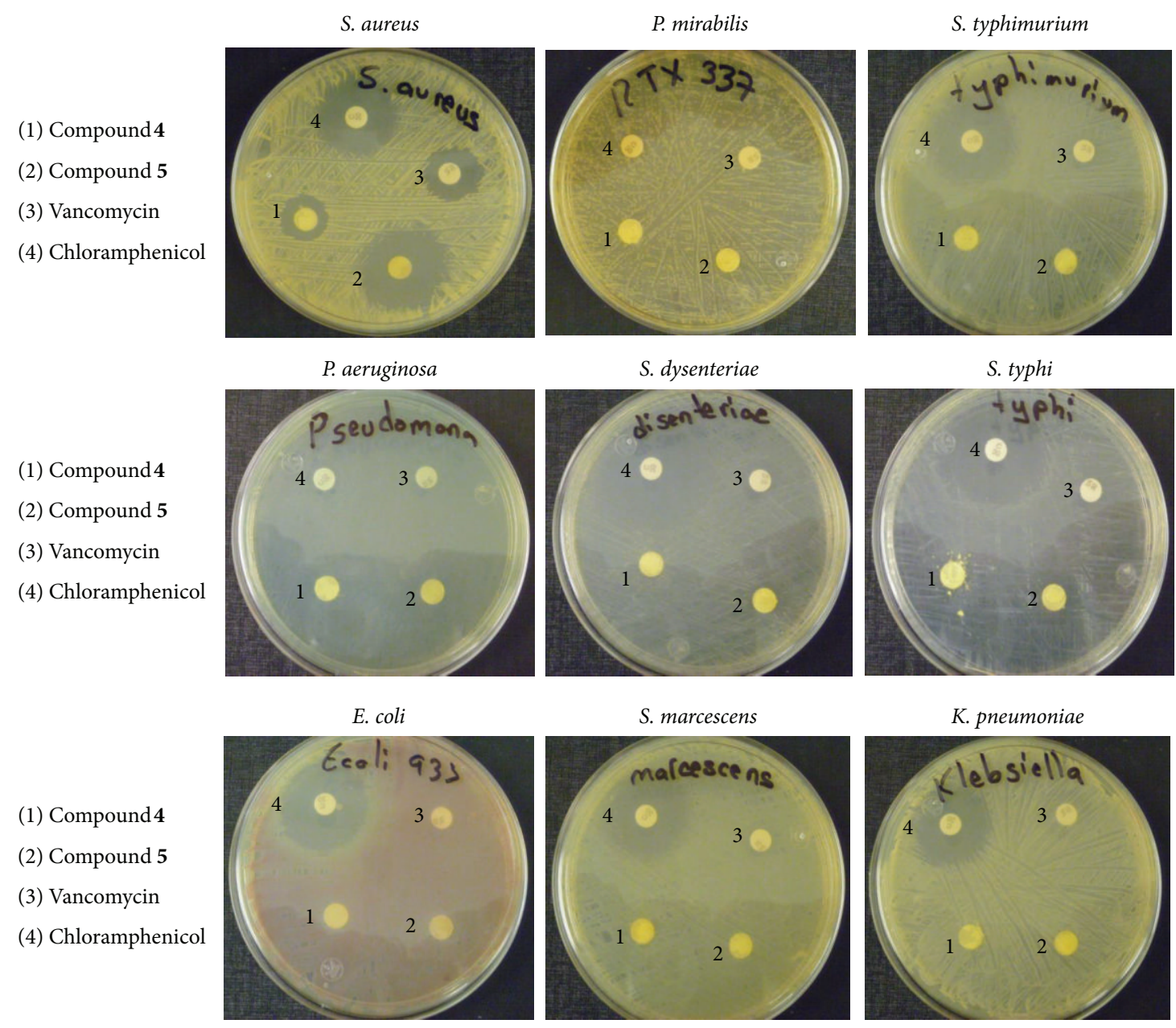

FIGURE 6: Photographs of the antimicrobial activities of compounds $\mathbf{4}$ and $\mathbf{5}$ against S. aureus, P. mirabilis, S. typhimurium, P. aeruginosa, S. dysenteriae, and S. typhi, showing their inhibition zone.

TABLE 3: Antimicrobial activity of organotin(IV) compounds 1-5.

\begin{tabular}{lccccc}
\hline \multirow{2}{*}{ Strain } & \multicolumn{5}{c}{ Compound } \\
& $\mathbf{1}$ & $\mathbf{2}$ & $\mathbf{3}$ & $\mathbf{4}$ & $\mathbf{5}$ \\
\hline Staphylococcus aureus & + & - & - & ++ & +++ \\
Proteus mirabilis RTX337 & + & + & - & - & - \\
Pseudomona aeruginosa & + & - & - & - & - \\
Salmonella typhi & - & + & - & - & - \\
Salmonella typhimurium & - & + & - & - & - \\
Escherichia coli 933 & - & + & - & - & - \\
Klebsiella & - & + & - & - & - \\
Serratia marcescens & - & - & - & - & - \\
Shigella dysenteriae & - & - & - & - & + \\
\hline
\end{tabular}

particular, organotin derivatives of amino acids containing $\mathrm{N}$-heterocycles bonded to the $\alpha$-carbon should be studied in more detail because of the well-known role of the histidine residue binding properties. In particular it is important to study the histidine binding properties to triorganotin compounds in order to provide evidence for important mechanisms of biological activities [30].
In order to study the potential biological properties of the synthesized compounds, the bactericidal properties are studied.

The degree of effectiveness was measured by determining the diameters of the zone of inhibition caused by the compound. The biological activity was then classified in 4 categories on the bases of their diameter of growth inhibition: $(+++)$ most effective, $(++)$ moderate effective, $(+)$ slightly effective, and (-) noneffective.

Compound $\mathbf{1}$ is slightly effective against both Grampositive and Gram-negative bacteria; $\mathbf{2}$ is moderately effective against Gram-negative bacteria; 3 does not show antibacterial activity at all. These results are comparable to related pentacoordinated tin(IV) compounds with Schiff bases derived from amino acids reported in the literature [2].

Compounds $\mathbf{4}$ and $\mathbf{5}$ are moderate effective and most effective, respectively, against Staphylococcus aureus strains (Gram-positive). Results are presented in Table 3 and Figures 5 and 6.

Thus the results clearly indicate that pentacoordinated tin(IV) compounds of Schiff bases derived from L-histidine have exhibited moderate to minimal bactericidal properties while tetracoordinated tin(IV) compounds have presented 
high activity against the Gram-positive methicillin-resistant S. aureus. Even more, compound $\mathbf{5}$ as observed in Figure 6 is more active when compared with standard references vancomycin and chloramphenicol against the same bacteria under identical experimental conditions. These are very promising results in particular for the triphenyltin(IV) derivative.

It has been described that triorganotin compounds are significantly more biocidally active than other classes [30], statement that is true based on the results of this work.

\section{Conclusions}

Five novel tin(IV) compounds have been synthesized. The compounds are coordinated to a histidine analogue. With the help of various physicochemical techniques, the structure of the newly synthesized compounds has been proposed (Figure 1). It has been spectroscopically demonstrated that the Schiff base ligand derived from L-histidine and 3,5-ditert-butyl-2-hydroxybenzaldehyde coordinates to tin(IV) in a tridentate and monodentate manner producing pentacoordinated and tetracoordinated tin(IV) compounds.

Amino acids are very difficult ligands to work with due to their many donor groups and reduced solubility in nonpolar solvents. Nevertheless it was possible to isolate pure compounds. The selection of the ligand, a biologically active amino acid, has produced metal-ligand combined effects that may result in an important improvement in the activity of the resulting coordination compounds.

The triphenyltin(IV) complex $\mathbf{5}$ has been found to be most active against the Gram-positive methicillin-resistant $S$. aureus.

With these results, it is important to stress the need of more research in the synthesis, isolation, and characterization of new organotin(IV) cations with biologically active ligands, in an effort to obtain important structure-activity relationships.

\section{Acknowledgment}

Ariadna Garza-Ortiz expresses gratitude to Universidad Autonoma Metropolitana-Xochimilco for the posdoctoral fellowship.

\section{References}

[1] S. Roy, K. D. Hagen, P. U. Maheswari et al., "Phenanthroline derivatives with improved selectivity as DNA-targeting anticancer or antimicrobial drugs," ChemMedChem, vol. 3, no. 9, pp. 1427-1434, 2008.

[2] L. Pellerito and L. Nagy, "Organotin(IV) ${ }^{n+}$ complexes formed with biologically active ligands: equilibrium and structural studies, and some biological aspects," Coordination Chemistry Reviews, vol. 224, no. 1-2, pp. 111-150, 2002.

[3] L. Casella and M. Gullotti, "Coordination modes of histidine: 4. Coordination structures in the copper(II)-L-histidine (1:2) system," Journal of Inorganic Biochemistry, vol. 18, no. 1, pp. 1931, 1983.
[4] R. I. Henkin, Metal-Albumin-Amino Acid Interactions: Chemical and Physiological Interrelationships, Plenum Publishing, New York, NY, USA, 1974.

[5] A. Garza-Ortiz, P. U. Maheswari, M. Siegler, A. L. Spek, and J. Reedijk, "Ruthenium(III) chloride complex with a tridentate bis(arylimino)pyridine ligand: synthesis, spectra, X-ray structure, 9-ethylguanine binding pattern, and in vitro cytotoxicity," Inorganic Chemistry, vol. 47, no. 15, pp. 6964-6973, 2008.

[6] M. Aslam, I. Anis, N. Afza, B. Ali, and M. R. Shah, "Synthesis, characterization and biological activities of a bidentate schiff base ligand: $\mathrm{N}, \mathrm{N}^{\prime}$-Bis(1-phenylethylidene)ethane-1,2-diamine and its transition metals (II) complexes," Journal of the Chemical Society of Pakistan, vol. 34, p. 391, 2012.

[7] F. Kayser, M. Biesemans, M. Gielen, and R. Willem, "Characterization of the dibutylstannylene derivative of pyridoxine by proton detected 2D heteronuclear correlation NMR," Magnetic Resonance in Chemistry, vol. 32, no. 6, pp. 358-360, 1994.

[8] J. C. Martins, R. Willem, and M. Biesemans, "A comparative investigation of the consistent valence and extensible systematic force fields. A case study on the conformation of erythromycin A in benzene," Journal of the Chemical Society, vol. 2, no. 7, pp. 1513-1520, 1999.

[9] C. Camacho-Camacho, I. Rojas-Oviedo, M. A. Paz-Sandoval et al., "Synthesis, structural characterization and cytotoxic activity of organotin derivatives of indomethacin," Applied Organometallic Chemistry, vol. 22, no. 3, pp. 171-176, 2008.

[10] M. Gielen, "Review: organotin compounds and their therapeutic potential: a report from the Organometallic Chemistry Department of the Free University of Brussels," Applied Organometallic Chemistry, vol. 16, no. 9, pp. 481-494, 2002.

[11] V. Valla and M. Bakola-Christianopoulou, "Chemical aspects of organotin derivatives of beta-diketones, quinonoids, steroids and some currently used drugs: a review of the literature with emphasis on the medicinal potential of organotins," Synthesis and Reactivity in Inorganic and Metal-Organic Chemistry, vol. 37, pp. 507-525, 2007.

[12] B. Y. K. Ho and J. J. Zuckerman, "Trialkyltin derivatives of amino acids and dipeptides," Inorganic Chemistry, vol. 12, pp. 1552-1561, 1973.

[13] H. Bruckner and K. Hartel, German Patent 1, 061, 561, 1959.

[14] M. Frankel, D. Gertner, D. Wagner, and A. Zilkha, "Organotin esters of amino acids and their use in peptide syntheses," Journal of Organic Chemistry, vol. 30, no. 5, pp. 1596-1599, 1965.

[15] B. Y. K. Ho and J. J. Zuckerman, "Structure organotin chemistry," Journal of Organometallic Chemistry, vol. 49, no. 1, pp. 184, 1973.

[16] A. Hamdan-Partida, T. Sainz-Espuñes, and J. Bustos-Martínez, "Characterization and persistence of Staphylococcus aureus strains isolated from the anterior nares and throats of healthy carriers in a mexican community," Journal of Clinical Microbiology, vol. 48, pp. 1701-1705, 2010.

[17] National Committee for Clinical Laboratory Standards, Document: M2-A9. National Committee for Clinical Laboratory Standards, Wayne, PA, 2006.

[18] C. Camacho-Camacho, I. Rojas-Oviedo, A. Garza-Ortiz, J. Cardenas, R. Alfredo Toscano, and R. Gavino, "Synthesis, structural characterization and in vitro cytotoxic activity of novel polymeric triorganotin(IV) complexes of urocanic acid," Applied Organometallic Chemistry, vol. 27, no. 1, pp. 45-51, 2013.

[19] B. S. Manhas and A. K. Trikha, "Relationships between the direction of shifts in the carbon-oxygen stretching frequencies 
of carboxylate complexes and the type of carboxylate coordination," Journal-Indian Chemical Society, vol. 59, p. 315, 1982.

[20] K. Nakamoto, Infrared and Raman Spectra of Inorganic and Coordination Compounds, Wiley, New York, NY, USA, 1980.

[21] M. Gielen, "Tin-based antitumour drugs," Coordination Chemistry Reviews, vol. 151, pp. 41-51, 1996.

[22] M. Pellei, S. Alidori, F. Benetollo et al., "Di- and triorganotin(IV) complexes of the new bis(1-methyl-1H-imidazol2-ylthio)acetate ligand and the decarboxylated analogues," Journal of Organometallic Chemistry, vol. 693, no. 6, pp. 996-1004, 2008.

[23] F. E. Smith, R. C. Hynes, T. T. Ang, L. E. Khoo, and G. Eng, "The synthesis and structural characterization of a series of pentacoordinate diorganotin(IV) $N$-arylidene- $\alpha$-amino acid complexes," Canadian Journal of Chemistry, vol. 70, no. 4, pp. 1114-1120, 1992.

[24] N. Kobakhidze, N. Farfan, M. Romero et al., "New pentacoordinated Schiff-base diorganotin(IV) complexes derived from nonpolar side chain $\alpha$-amino acids," Journal of Organometallic Chemistry, vol. 695, no. 8, pp. 1189-1199, 2010.

[25] C. Camacho-Camacho, A. Esparza-Ruiz, A. Vásquez-Badillo, H. Nöth, A. Flores-Parra, and R. Contreras, "Fused hexacyclic tin compounds derived from 3-(3,5-di-t-butyl-2-hydroxyphenylimino)-3H-phenoxazin-2-ol," Journal of Organometallic Chemistry, vol. 694, no. 5, pp. 726-730, 2009.

[26] M. Gielen, M. Biesemans, and R. Willem, "Organotin compounds: from kinetics to stereochemistry and antitumour activities," Applied Organometallic Chemistry, vol. 19, pp. 440450, 2005.

[27] M. Gielen and E. R. T. Tiekink, 50Sn Tin Compounds and Their Therapeutic Potential, John Wiley \& Sons, Chichester, UK, 2005.

[28] R. Willem, A. Bouhdid, M. Biesemans et al., "Synthesis and characterization of triphenyl- and tri-n-butyltin pentafluorobenzoates, -phenylacetates and -cinnamates. X-ray structure determination of tri-n-butyltin pentafluorocinnamate," Journal of Organometallic Chemistry, vol. 514, no. 1-2, pp. 203-212, 1996.

[29] R. Willem, I. Verbruggen, M. Gielen et al., "Correlating Mössbauer and solution- and solid-state 117Sn NMR data with $\mathrm{x}$-ray diffraction structural data of triorganotin 2[(E)-2-(2-hydroxy-5-methylphenyl)-1-diazenyl]benzoates," Organometallics, vol. 17, no. 26, pp. 5758-5766, 1998.

[30] K. C. Molloy, Bioorganotin Compounds, John Wiley and Sons, London, UK, 1989. 

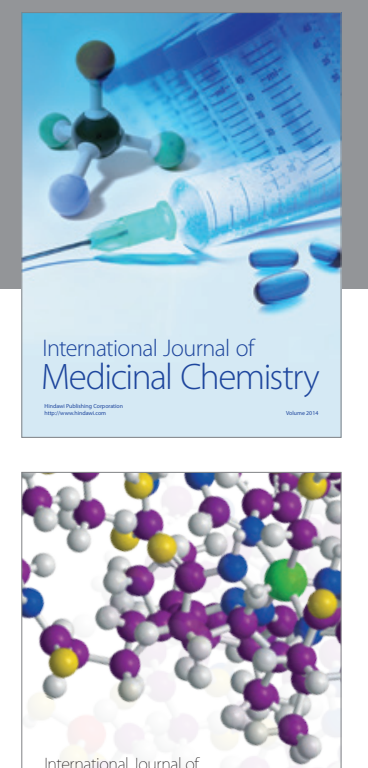

\section{Carbohydrate} Chemistry

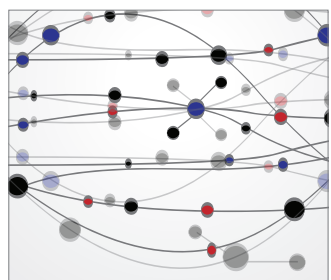

The Scientific World Journal
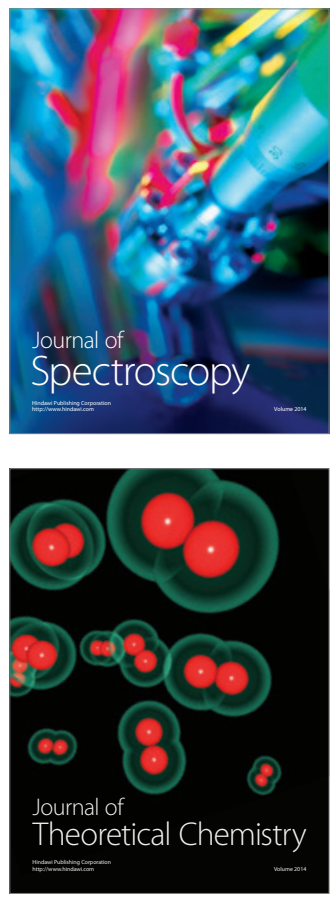
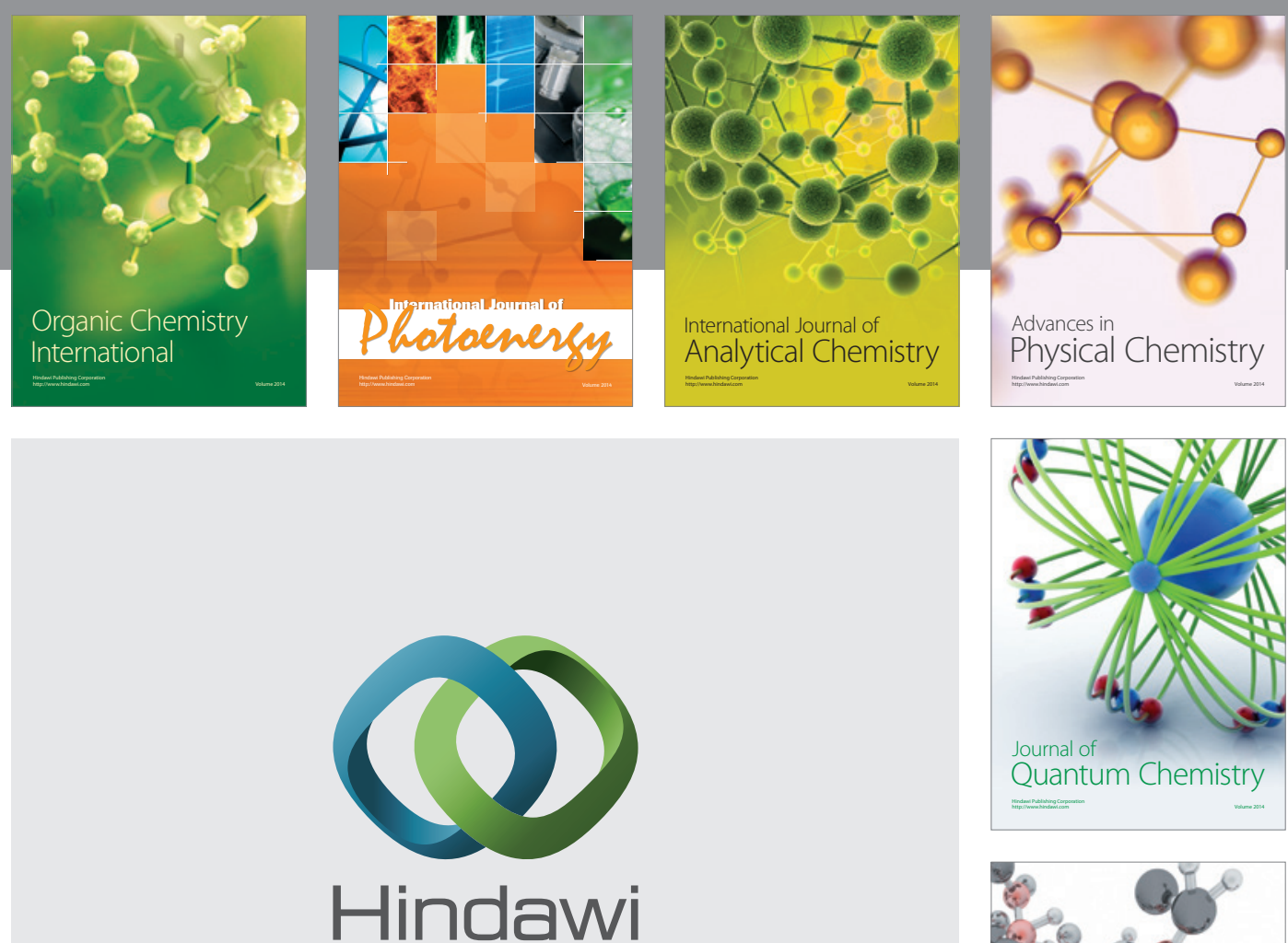

Submit your manuscripts at

http://www.hindawi.com

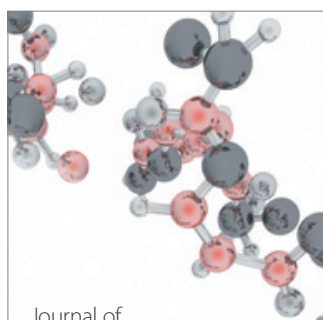

Analytical Methods

in Chemistry

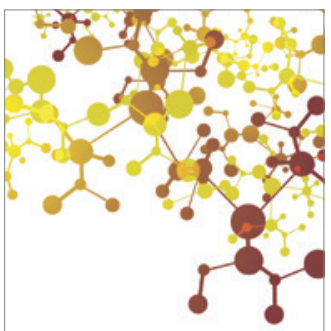

Journal of

Applied Chemistry

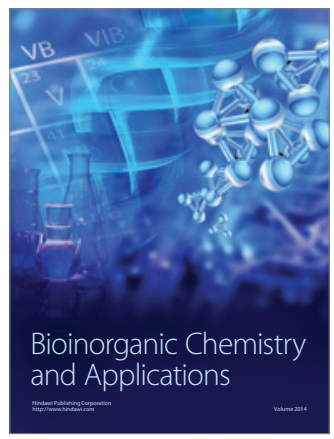

Inorganic Chemistry
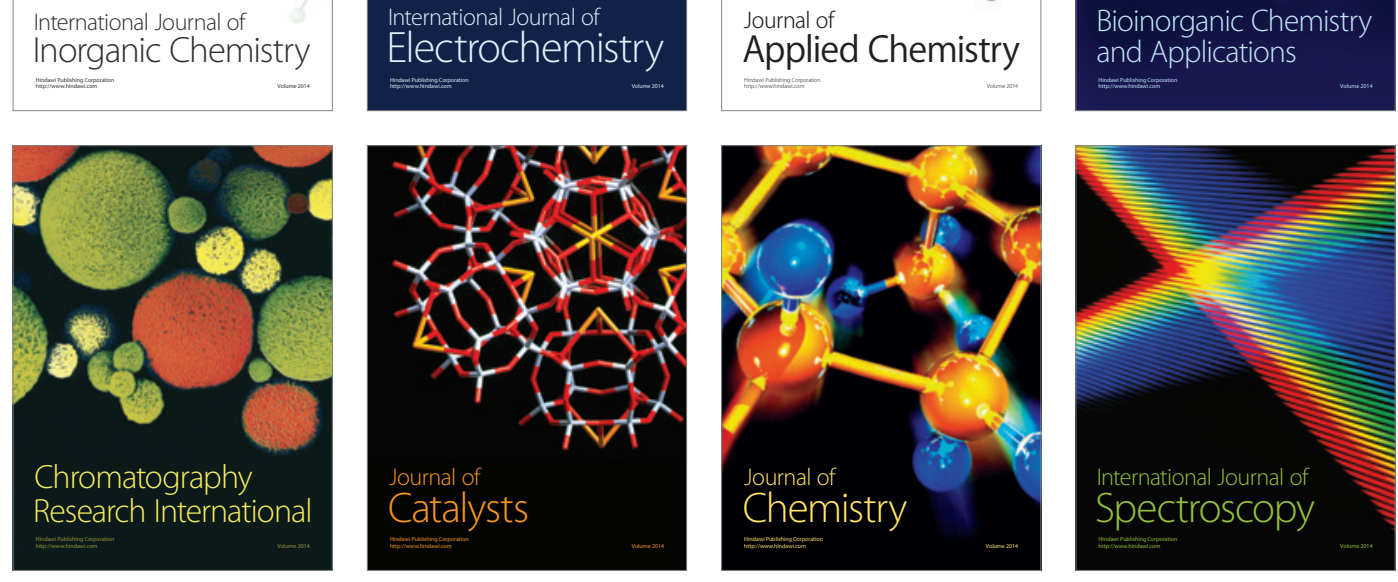